\title{
Hepatoprotective Activity of Gentisic Acid on 5-Fluorouracil-induced Hepatotoxicity in Wistar Rats
}

\section{Wistar Sıçanlarında Gentisik Asidin 5-Florourasil Kaynaklı Hepatotoksisite Üzerindeki Hepatoprotektif Aktivitesi}

\author{
(D) Rohini Revansiddappa PUJARI ${ }^{1 *}$, (D) Deepti Dinesh BANDAWANE2 \\ ${ }^{1}$ Modern College of Pharmacy (for Ladies), Department of Pharmacology, Maharashtra, India \\ 2Modern College of Pharmacy, Department of Pharmacology, Maharashtra, India
}

\begin{abstract}
Objectives: 5-Fluorouracil (5-FU) is a very potent and effective antineoplastic drug that has been widely used for the management of various types of cancer. However, the clinical use of $5-\mathrm{FU}$ is often associated with severe toxicities including hepatotoxicity, which limit its therapeutic use as a potent anticancer agent. The present study aimed to evaluate the hepatoprotective activity of a plant phenolic acid, gentisic acid (GA) (2,5-dihyroxybenzoic acid), against hepatotoxicity induced by 5-FU administration in Wistar rats.

Materials and Methods: The rats were randomly divided into six groups, with six rats per group. Among these, group I and II served as normal control and 5-FU control groups, respectively. The rats in these groups received distilled water (1 mL/kg) for 14 days by oral route. Groups III, IV, $\mathrm{V}$, and VI served as test groups and received GA at doses of $3,10,30$, and $100 \mathrm{mg} / \mathrm{kg}$ body weight, respectively, via oral route for 14 days. From Day 9 onwards, all the groups, except group I, received intraperitoneal dose of $5-F U$ ( $20 \mathrm{mg} / \mathrm{kg}$ body weight) for five days up to day 14 . At the end of the study, the rats were sacrificed, blood was withdrawn for biochemical estimations, and hepatic tissues were excised for histopathological evaluations.

Results: Administration of 5-FU at a dose of $20 \mathrm{mg} / \mathrm{kg}$ body weight resulted in a significant increase in the serum levels of hepatic biomarkers, including aspartate aminotransferase, alanine aminotransferase, alkaline phosphatase, direct bilirubin, and total bilirubin. In comparison to these, 5-FU treatment resulted in a reduction in total protein content (TPC). This was accompanied by significant histopathological changes in the hepatic tissues of the rats, indicating severe hepatotoxicity. Pre- and co-administration of GA with 5-FU at doses of 30 and 100 mg/kg body weight for 14 days resulted in a dose-dependent amelioration of the 5-FU induced alterations in the biochemical and histopathological parameters.

Conclusion: The results of the study highlighted the potential of GA as a hepatoprotective agent for the prevention of 5-FU-induced hepatotoxicity. Key words: 5-Fluorouracil, gentisic acid, 2,5-dihyroxybenzoic acid, hepatotoxicity, plant phenolics, hepatoprotective, cancer chemotherapy
\end{abstract}

ÖZ

Amaç: 5-Florourasil (5-FU), çeşitli kanser türlerinin tedavisinde yaygın olarak kullanılan çok güçlü ve etkili bir antineoplastik ilaçtır. Bununla birlikte, 5-FU'nun klinik kullanımı genellikle, güçlü bir antikanser ajan olarak terapötik kullanımını sınırlayan hepatotoksisite dahil olmak üzere ciddi toksisitelerle ilișkilidir. Bu çalıșmada, Wistar sıçanlarında 5-FU uygulaması ile uyarılan hepatotoksisiteye karșı bir bitki fenolik asiti olan gentisik asidin (GA) (2,5-dihiroksibenzoik asit) hepatoprotektif aktivitesini değerlendirmeyi amaçladık.

Gereç ve Yöntemler: Sıçanlar rastgele olarak grup başına altı sıçan olacak şekilde altı gruba ayrıldı. Bunlar arasında grup I ve II, sırasıyla normal kontrol ve 5-FU kontrol grupları olarak belirlendi. Bu gruplardaki sıçanlar 14 gün boyunca oral yolla damıılmış su (1 mL/kg) aldı. Gruplar III, IV, V ve VI test grupları olarak görev yaptı ve 14 gün boyunca oral yoldan sırasıyla 3, 10, 30 ve $100 \mathrm{mg} / \mathrm{kg}$ vücut ağırlığı dozlarında GA aldı. Dokuzuncu günden itibaren, grup I hariç tüm gruplar, 14. güne kadar beş gün boyunca 5-FU (20 mg/kg vücut ağırlığı) intraperitoneal doz aldı. Çalıșmanın sonunda, biyokimyasal analiz için kanları alındıktan sonra sıçanlar sakrifiye edildi ve hepatik dokular histopatolojik değerlendirmeler için eksize edildi.

Bulgular: 20 mg/kg vücut ağırlığı dozunda 5-FU uygulaması aspartat aminotransferaz, alanin aminotransferaz, alkalen fosfataz, bilirubin ve toplam bilirubin dahil olmak üzere hepatik biyobelirteçlerin serum seviyelerinde önemli bir artışa neden olmuștur. Bunlarla karşılaştırıldığında, 5-FU tedavisi toplam protein içeriğinde bir azalmaya yol açtı. Buna, sıçanların hepatik dokularında şiddetli hepatotoksisiteyi gösteren önemli histopatolojik değişiklikler eşlik etti. GA'nın 14 gün boyunca 30 ve 100 mg/kg vücut ağırlığı dozlarında 5-FU ile önceden ve birlikte uygulanması, biyokimyasal ve histopatolojik parametrelerde 5-FU kaynaklı değişikliklerde doza bağlı bir iyileșme ile sonuçlanmıştır.

Sonuç: Çalışmanın sonuçları, GA'nın 5-FU ile indüklenen hepatotoksisitenin önlenmesi için bir hepatoprotektif ajan olarak potansiyelini vurguladı. Anahtar kelimeler: 5-Florourasil, gentisik asit, 2,5-dihiroksibenzoik asit, hepatotoksisite, bitki fenolikleri, hepatoprotektif, kanser kemoterapisi 


\section{INTRODUCTION}

Cancer is one of the leading causes of death worldwide. It accounted for $\sim 10$ million deaths in the year 2020. Chemotherapy is a standard cancer therapy that is used either alone or in combination with surgery or radiation therapy (neoadjuvant and adjuvant therapy). Despite its success in killing cancer cells, chemotherapy-induced hepatotoxicity and impairment of liver function limit its application. The adverse clinical complications associated with chemotherapy often require dose reduction or withdrawal of chemotherapeutic agents, thereby limiting their therapeutic potential as effective antineoplastic agents. Thus, the negative aspects associated with the administration of chemotherapeutic drugs limit their clinical application, regardless of their contribution in the improvement of patient survival rate., ${ }^{1,2}$

5-Fluorouracil (5-FU) is a fluorinated pyrimidine analog, which is widely used in the management of various types of cancer, including stomach, breast, head and neck, colorectal, and genitourinary cancers. ${ }^{3}$ It is used either alone or in combination with other drugs. 5-FU generally acts via incorporation into both DNA and RNA. The administration 5-FU results in the incorporation of deoxyuridine triphosphate and fluorodeoxyuridine triphosphate molecules into DNA via replacement of reduced thymidine triphosphate (TTP).$^{4}$ Incorporation of fluorodeoxyuridylate and deoxyuridylate in DNA is accompanied by initiation of excision-repair process, which results in the breakage of DNA strand owing to the absence of TTP. This is generally mediated via blockade of the enzyme activity of thymidylate synthase. The insertion of 5-FU into RNA severely affects the functioning as well as processing of RNA, which further results in severe toxicities. ${ }^{5}$-FU chemotherapy has been reported to exhibit severe systemic toxicities, including hepatotoxicity, in clinical practice. ${ }^{6}$ Generally, $5-\mathrm{FU}$ is eliminated from the body via hepatic metabolism. Dihydropyrimidine dehydrogenase enzyme found in the liver is the key enzyme that catalyzes the rate-limiting step in 5-FU catabolism. Toxic intermediates produced during the metabolism of 5-FU are majorly responsible for liver injury. ${ }^{7}$ Various in vitro and in vivo studies have demonstrated that administration of 5-FU is accompanied by induction of oxidative stress in the liver, which consequently results in the structural and functional disruption of hepatocytes. Thus, devising strategies to reduce 5-FU associated hepatotoxicity might prove beneficial for improving the overall clinical outcomes of this chemotherapeutic agent. ${ }^{8-10}$

Since the primordial era, plants have been successfully used as therapeutic agents to cure various ailments. Currently, sincere efforts are being invested to harness the therapeutic potential of the phytoconstituents, having antiapoptotic, antioxidant, and antiinflammatory properties, to reduce the cancer chemotherapy-induced drug toxicities. ${ }^{11,12}$ Several preclinical studies have reported beneficial effects of daily consumption of fruits and vegetables, particularly in decreasing the risk of neoplasm. This effect is majorly contributed by the presence of various essential nutrients, predominantly phenolics, in fruits and vegetables. ${ }^{13}$ Phenolic acids are the most extensively distributed secondary metabolites in the plant kingdom and about 10,000 structures of plant phenolics are known. These compounds have been widely investigated and several preclinical studies have established their importance for human well-being. ${ }^{14,15}$

Gentisic acid (GA) is a phenolic compound that has been shown to exert beneficial effects on human health. Various pharmacological activities have been reported for GA including analgesic, antiarthritic, antiinflammatory, antimutagenic, anticancer, antirheumatic, and antispasmodic activities. In addition to these, it is also known to exert antiparkinsonian, antifungal, iron chelation, and siderophoric effects. Evidences are available for its antihyperlipidemic activity, protective activity against cyclophosphamide-induced genotoxicity, and inhibitory activity against fibroblast growth factor. Besides these, antioxidant effects of GA have been reported in both in vivo and in vitro studies. ${ }^{16-28}$ In a previous study, GA has been shown to ameliorate cyclophosphamide-induced hepatotoxicity in vivo. The results of the study showed that both pre- and co-treatment with GA at doses of 50 and $100 \mathrm{mg} /$ $\mathrm{kg}$ body weight ameliorated the cyclophosphamide-induced increase in malondialdehyde levels. This was accompanied by normalization of the levels of all oxidative stress biomarkers, including glutathione peroxidase, glutathione reductase, glutathione, catalase, and quinone reductase. GA administration also resulted in a reduction in DNA fragmentation and formation of micronuclei. Additionally, pre- and co-treatment with GA ameliorated the cyclophosphamide-induced increase in the hepatic biomarkers, such as alanine aminotransferase (ALT), lactate dehydrogenase, and aspartate aminotransferase (AST). ${ }^{29}$ Currently, no reports are available for the protective effects of GA against the hepatotoxicity induced by anticancer agents including 5-FU.

The present study aimed to evaluate the protective activity of GA against 5-FU-induced hepatotoxicity. The study involved quantitative estimation of the enzymes, involved in hepatic function, in the serum. Histopathological investigations were carried out to evaluate the ultrastructural alterations in the hepatic tissue arising due to 5-FU treatment.

\section{MATERIALS AND METHODS}

\section{Chemicals and kits}

GA was procured from Sigma-Aldrich Chemicals, USA. 5-FU (fiveflurd) was purchased from GlaxoSmithKline Pharmaceuticals Ltd. Mumbai, Maharashtra, Analytical grade solvents and chemicals used in the study were obtained from Oswal Chemicals, New neeta Chemicals and Loba Chemie Pvt. Ltd., Pune, Maharashtra, India. Diagnostic kits used for biochemical analysis were procured from Biolab Diagnostics Pvt. Ltd., Kiran Enterprises, Pune, India.

\section{Animals}

For in vivo experiments, 8-12 weeks old adult Wistar rats (200-250 g) from either sex were used. These rats were 
purchased from the National Institute of Biosciences, Pune, Maharashtra. Upon arrival, the rats were caged in groups of 5-6 rats in standard polypropylene cages having a wire mesh lid. The rats were maintained under standard environmental conditions, at a temperature of $25^{\circ} \mathrm{C} \pm 2^{\circ} \mathrm{C}$ with $45 \%-55 \%$ relative humidity and $12 / 12 \mathrm{~h}$ light/dark cycle, in the institutional animal house facility. The animals had free access to standard pelleted chow (Nutrivet Life Sciences, Pune, India) and water during the entire course of the study. The animals were acclimatized upto 04 days prior to the experimental procedures. All experimental procedures were performed during the day time, between 12:00 and 16:00 h. The animals were transferred from the animal house facility to the experimental laboratory one hour prior to the experiments.

\section{Ethical clearance}

All the experimental procedures included in the study were carried out in compliance with the Institutional Animal Ethical Committee (IAEC) Guidelines given as per the Committee for the Purpose of Control and Supervision of Experiments on Animals, New Delhi, India (Section-15 of the Prevention of Cruelty to Animals Act, 1960; Ministry of environment and forest, Government of India). The experimental protocols were approved by IAEC of Modern College of Pharmacy, Yamunanagar Nigdi, Pune-411044 (proposal no: MCP/IAEC/004/2017; date: 07/11/2017).

\section{Preparation of drug solutions}

GA stock solutions, at concentrations of $3,10,30$, and 100 $\mathrm{mg} / \mathrm{mL}$, were prepared by dissolving desired amount of GA in distilled water. For $5-\mathrm{FU}$, a stock solution of $20 \mathrm{mg} / \mathrm{mL}$ was prepared by dissolving required amount of 5-FU in distilled water. The selection of stock solutions was made according to the required dose of administration.

\section{Experimental design}

The rats were randomly divided into six groups, with six rats per group. Group I and II served as normal control and 5-FU control groups, respectively. The rats in these two groups received distilled water $(1 \mathrm{~mL} / \mathrm{kg}$ body weight) orally for 14 days. Groups III, IV, V, and VI served as test groups and received oral doses of $\mathrm{GA}$ at concentrations of 3,10 , 30 , and $100 \mathrm{mg} / \mathrm{kg}$ body weight, respectively, for 14 days. From Day 9 onwards, all groups, except group I, received intraperitoneal dose of $5-\mathrm{FU}$ ( $20 \mathrm{mg} / \mathrm{kg}$ body weight) for five days up to day 14.

At the end of the experiment, the rats were sacrificed by cervical dislocation. Blood samples were obtained by cardiac puncture and collected in serum separation tubes. The serum was obtained from the collected samples by centrifugation at $3000 \mathrm{rpm}$ at $20^{\circ} \mathrm{C}$ for $20 \mathrm{~min}$. Post centrifugation, the serum was carefully transferred into Eppendorf tubes and stored at $-20^{\circ} \mathrm{C}$. These sera samples were used for the assessment of hepatic biomarkers. Following this, the livers were excised, washed using ice-cold saline solution, dried, and stored at $-80^{\circ} \mathrm{C}$ to $-20^{\circ} \mathrm{C}$ until used for further analysis. ${ }^{29}$

\section{Estimation of hepatic biomarkers}

The levels of alkaline phosphatase (ALP), AST, ALT, total bilirubin (TB), direct bilirubin (DB), and total protein content (TPC) in the collected serum samples were estimated using standard biochemical estimation kits. These assays involved spectrophotometric measurements that were performed using a utlraviolet (UV)-2600 UV-visible spectrophotometer (Shimadzu Corporation).

\section{Histopathological studies}

For fixation, the whole intact liver specimens were treated with formalin (10\%, v/v) for 24 hours. Following this, the samples were embedded in paraffin. A rotary microtome (Biocraft) was used to obtain representative coronal slices ( $5 \mu \mathrm{m}$ thickness) of organs. Further, these coronal slices were stained with hematoxylin for $8 \mathrm{~min}$, followed by staining with eosin for 3 min Luna. ${ }^{30}$ Permanent slides were prepared using these thin sections. These slides were visualized under a lens with $45 x$ magnification power using a digital trinocular microscope (Olympus CX-21-TR), available at the institutional imaging facility. The photomicrographs were captured with the help of Magnuspro eyepiece camera software.

\section{Statistical analysis}

The results were expressed as mean \pm standard error of mean. For comparison between the groups, One-Way ANOVA was performed, followed by Tukey's Kramer Multiple Comparison test using Instat Graph Pad software (version 3).

\section{RESULTS}

\section{Estimation of hepatic biomarkers}

In the present study, the levels of serum hepatic biomarkers, including ALP, AST, ALT, TB, DB, and TPC, were estimated using biochemical assays. As shown in Figure 1, 2, the administration of 5 -FU resulted in a significant $(p<0.001)$ increase in the serum levels of ALP, AST, ALT, TB, and DB levels; however, a significant reduction in TPC levels was observed in the 5-FU control group as compared to the normal control group. In comparison to this, pre- and co-treatment with GA at the doses of 30 and $100 \mathrm{mg} /$ $\mathrm{kg}$ body weight resulted in a dose-dependent amelioration of the alterations in the hepatic biomarkers, with statistical significance of $p<0.01$ and 0.001 , respectively (Figure 1, 2).

\section{Histopathological studies of hepatic tissue}

Histopathological investigation of the hepatic tissues for the normal control group showed the presence of normal hepatocytes and central vein. In comparison to this, liver specimen for 5-FU control group rats were characterized by marked reactive changes, suggestive of hydropic degeneration (HD) of the hepatocytes and focal necrosis at the central vein zone along with the disruption of the hepatic central vein $(\mathrm{HCV})$. The pre- and co-treatment with GA resulted in a dosedependent amelioration of these histopathological alterations. As shown in Figure 3, GA administration at doses of 30 and 100 $\mathrm{mg} / \mathrm{kg}$ body weight showed moderate and marked improvement, respectively, in the histopathological alterations of the liver tissues. 


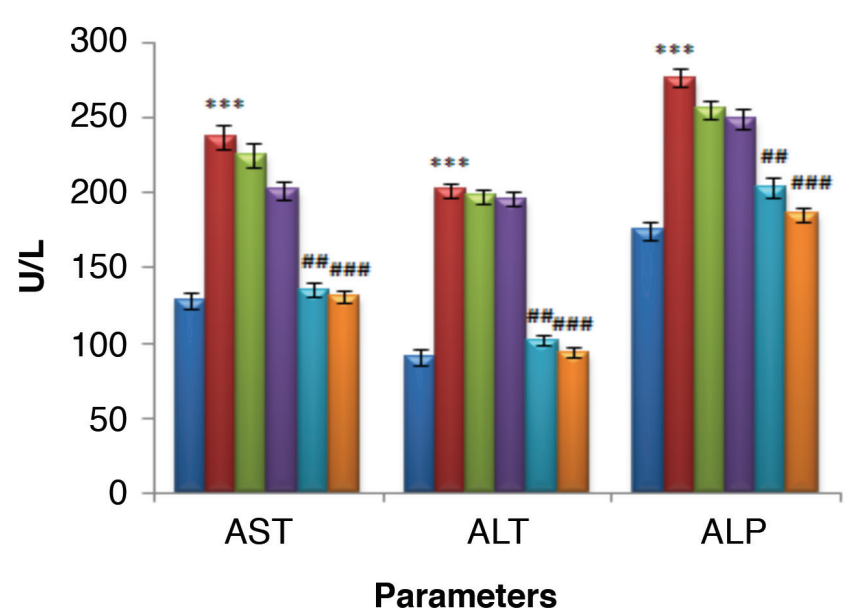

\author{
Normal Control $\square \mathrm{GA}(10)+5-\mathrm{FU}$ \\ $\square$ 5-FU Control $\square \mathrm{GA}(30)+5-\mathrm{FU}$ \\ $\square \mathrm{GA}(3)+5-\mathrm{FU} \square \mathrm{GA}(100)+5-\mathrm{FU}$
}

Figure 1. Effect of GA on serum levels of AST, ALT and ALP in 5-FUinduced hepatotoxicity in rats. Results were expressed as mean \pm SEM $(n=6)$. Comparison between the groups was carried out using One-Way ANOVA, followed by Tukey's Kramer Multiple Comparison test.

${ }^{* * *}$ p $<0.001$ as compared to normal control, \#\#<0.01, \#\#\#<0.001 as compared to 5-FU induced control group, SEM: Standard error of mean, GA: Gentisic acid, AST: Aspartate aminotransferase, ALT: Alanine aminotransferase, ALP: Alkaline phosphatase, 5-FU: 5-Fluorouracil

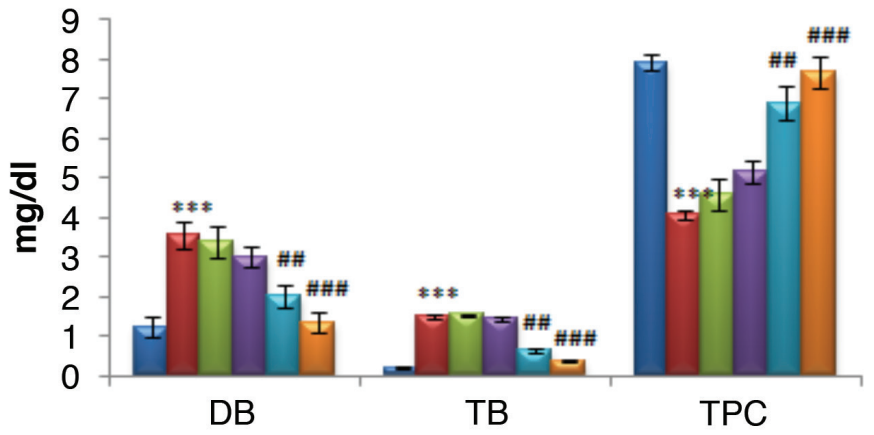

\section{Parameters}

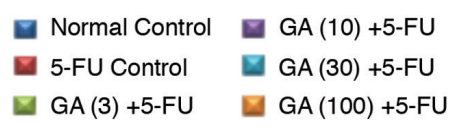

Figure 2. Effect of GA on serum levels of DB, TB, and TPC in 5-FU-induced hepatotoxicity in rats. Results were expressed as mean \pm SEM $(n=6)$. Comparison between the groups was performed using One-Way ANOVA, followed by Tukey's Kramer Multiple Comparison test.

${ }^{* * *}$ p $<0.001$ as compared to normal control, \#\#p<0.01, \#\#\#p<0.001 as compared to 5-FU-induced control, GA: Gentisic acid, DB: Direct bilirubin, TB: Total bilirubin, TPC: Total protein content, 5-FU: 5-Fluorouracil, SEM: Standard error of mean
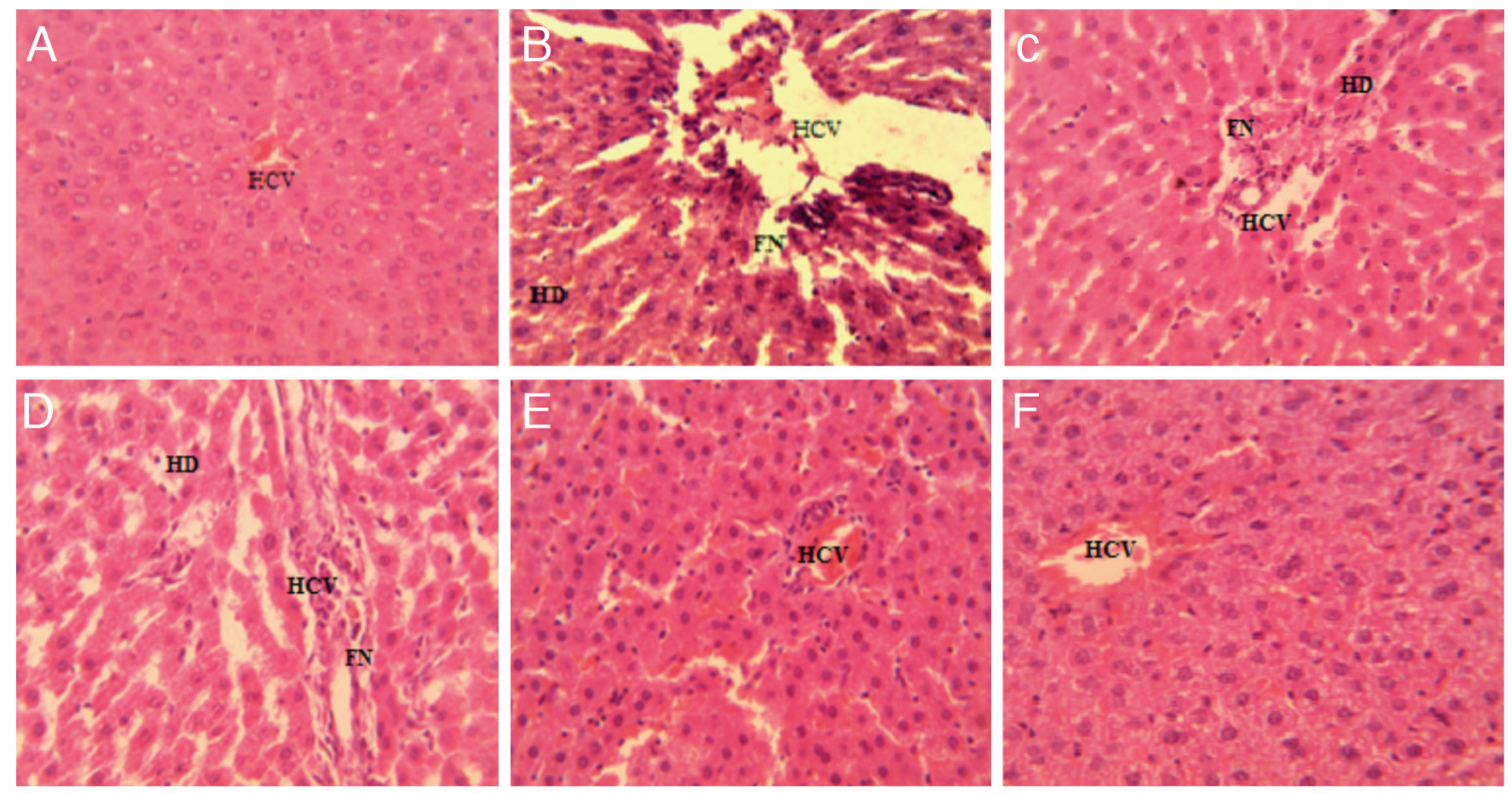

Figure 3. Histopathological investigations for effect of GA on 5-FU-induced hepatotoxicity representative photomicrographs (H \& E stain) for liver sections of: (A) Normal control rats showing normal liver architecture with normal hepatic central vein (HCV) and hepatocytes; (B) 5-FU control rats showing marked reactive changes, suggestive of hydropic degeneration (HD) of the hepatocytes as well as focal necrosis (FN) at central vein zone with the disruption of the $\mathrm{HCV}$; (C) GA ( $3 \mathrm{mg} / \mathrm{kg}$ body weight) + 5-FU and (D) GA (10 mg/kg body weight) + 5-FU group rats showing reactive changes similar to 5-FU control with no improvement; (E) GA (30 mg/kg body weight) + 5-FU rats showing a moderate reduction in the reactive changes caused by 5-FU; (F) GA (100 mg/kg body weight +5 -FU showing marked amelioration of histological alterations caused by 5 -FU. Photographs were taken under $45 x$ magnification power using a trinocular microscope (Olympus CX-21-TR) with Magnuspro eyepiece camera software

GA: Gentisic acid, 5-FU: 5-Fluorouracil, H \& E: Hematoxylin and eosin 


\section{DISCUSSION}

The liver is the central organ involved in the detoxification and clearance of waste products. Frequent administration of high doses of chemotherapeutic agents for cancer treatment has been shown to be associated with hepatotoxicity. ${ }^{31} 5$-FU is an important drug that has been widely used for cancer treatment. Since 5-FU is mainly metabolized in the liver, its administration is often associated with hepatotoxicity. The toxic metabolites produced by 5-FU tend to initiate hepatic injury resulting in severe hepatotoxicity, which limits the chemotherapeutic utility of 5-FU as an efficacious anticancer agent. 5-FU induced hepatotoxicity generally involves increase in apoptosis, oxidative stress, and inflammatory reactions. ${ }^{29}$ In the present study; the levels of different hepatic biomarkers were evaluated to confirm 5-FU-induced hepatotoxicity.

Generally, serum transaminases such as AST, ALT, and ALP are used as important indicators of hepatic damage. ${ }^{32}$ Among these, ALT is an important cytosolic enzyme that is more specific for the liver. AST is generally located in the hepatic mitochondria. The obstruction or inflammation of the biliary tract has been shown to result in an increase in ALP activity in plasma. ${ }^{33}$ Increased levels of ALP in the blood are majorly contributed by leakage of these transaminases from the hepatocytes into the circulation, indicating liver damage or dysfunction. ${ }^{32}$ In the present study, administration of 5-FU resulted in a significant increase in the levels of hepatic biomarkers, including ALP, AST, ALT, DB, and TB, as compared to the normal control group. Besides this, 5-FU treated group showed decrease in TPC. All these results suggested that 5-FU administration was associated with severe hepatotoxicity. These results were in agreement with the previous studies. ${ }^{29}$ In the treatment groups of the present study, pre- and co-treatment with GA resulted in the reversal of transaminase levels to normal. These results suggested hepatoprotective activity of GA, which was probably mediated by the reduction of hepatic injury and inflammation. Total and DB levels are generally used as indicators for the normal functioning of the liver. An increase in total and DB levels has been found to be associated with hepatic disorders, indicating severe hepatic damage leading to jaundice. ${ }^{34}$ In the present study, GA administration resulted in the reduction in the elevated levels of bilirubin that were induced by 5-FU treatment. Thus, all these results indicated the hepatoprotective potential of GA, highlighting its usefulness in ameliorating the side effects arising from the use of 5-FU therapy for various hepatic disorders.

TPC in serum provides an estimate for the total number of proteins present in the body fluids. Since the liver is involved in the synthesis of various proteins in the body, low protein content is used as an important marker for hepatic damage and dysfunction in various hepatic disorders. ${ }^{35}$ In the present study, pre- and co-treatment with GA resulted in an overall improvement in the TPC post 5-FU administration. These results further established the hepatoprotective activity of GA mediated by the reduction of hepatic damage and dysfunction. Thus, all these observations highlighted the potential of GA as a protective agent to ameliorate 5-FU-induced hepatotoxicity. ${ }^{36}$
Histophathological examination is one of the most important investigation that is required to establish the protective role of drugs against vital organ toxicities. ${ }^{35}$ In order to confirm the results obtained for the biochemical estimations, histopathological studies were also performed for the hepatic tissue excised from the rats at the end of the study. In the present study, significant histopathological changes were observed in the hepatic tissues of the 5-FU control group as compared to the normal control group. These changes provided visual evidences for the hepatotoxicity induced by 5-FU administration. These results were in agreement with the alterations reported for hepatic biomarkers in the biochemical assay. Treatment with 5-FU resulted in HD and necrosis of the hepatocytes with the HCV disruption. Similar histopathological alterations have been reported in several previous studies. ${ }^{37}$ 5-FU-induced hepatoxicity generally involves hepatic inflammation, apoptosis, and oxidative stress. GA has been previously reported to possess antiinflammatory and antioxidant properties, which might be responsible for this hepatoprotective effect of GA against 5-FU-induced hepatotoxicity. In a previous study, GA was shown to exert hepatoprotective effect against cyclophosphamide-induced hepatotoxicity. This hepatoprotective activity involved restoration of hepatic antioxidant levels and reduction of micronuclei formation and DNA fragmentation. ${ }^{28}$ A similar mechanism might also be responsible for GA mediated amelioration of 5 -FU-induced hepatotoxicity. A better understanding regarding the underlying mechanism involved in the hepatoprotective activity of GA would ensure true utilization of this protective agent.

\section{CONCLUSION}

In the present study, administration of 5-FU exhibited severe hepatotoxicity which was confirmed by severe alterations in both biochemical and histopathological parameters. Further, pre- and co-treatment with GA resulted in the attenuation of 5-FU-induced hepatotoxicity. GA administration ameliorated 5-FU-induced hepatic alterations in a significant and dosedependent manner. The chemoprotective potential of GA might be attributed to its antiinflammatory and antioxidant properties. All these results provided strong evidence to support the hypothesis that pre- and co-administration of GA could overcome 5-FU chemotherapy-induced toxicities. Thus, the use of GA might prove beneficial for the well-being of cancer patients, both during and after the chemotherapy. In addition to this, it might also enhance the overall life expectancy of the cancer patients. In order to utilize the true potential of GA as a protective agent, future studies must unravel the mechanism of action of GA and optimize the correct dose for human use. The conclusions drawn from the present study can be efficiently utilized to design suitable clinical studies to evaluate GA efficacy and safety in humans.

\section{ACKNOWLEDGMENTS}

All the authors are grateful to Dr. P. D. Chaudhari, Principal, Modern College of Pharmacy, Nigdi, Pune and Dr. S. N. Dhole, 
Principal, Modern College of Pharmacy (For Ladies), Moshi, Pune for providing access to the facilities and their guidance and support.

Conflicts of interest: No conflict of interest was declared by the authors. The authors alone are responsible for the content and writing of the paper.

\section{REFERENCES}

1. Perry MC. Chemotherapeutic agents and hepatotoxicity. Semin Oncol. 1992;19:551-565.

2. Zimmerman HJ. Hepatotoxic effects of oncotherapeutic and immunosuppressive agents. In: Zimmerman $\mathrm{HJ}$, ed. Hepatotoxicity: the adverse effects of drugs and other chemicals on the liver, ( $\left.2^{\text {nd }} e d\right)$. Philadelphia: Lippincott Williams \& Wilkins: 1999;673-708.

3. Caballero GA, Ausman RK, Quebbeman EJ. Long-term, ambulatory, continuous IV infusion of 5-FU for the treatment of advanced adenocarcinomas. Cancer Treat Rep. 1985;69:13-15.

4. Ghoshal K, Jacob ST. An alternative molecular mechanism of action of 5-fluorouracil, a potent anticancer drug. Biochem Pharmacol. 1997;53:1569-1575.

5. Backus HH, Pinedo HM, Wouters D, Kuiper CM, Jansen G, van Groeningen CJ, Peters GJ. Differences in the induction of DNA damage, cell cycle arrest and cell death by 5 -fluorouracil and antifolates. Oncol Res. 2000;12:231-239.

6. Moertel CG, Fleming TR, MacDonald JS, Haller DG, Laurie JA. Hepatic toxicity associated with fluorouracil, levamisole adjuvant therapy. J Clin Oncol. 1993;11:2386-2390.

7. Tateishi T, Watanabe M, Nakura H, M Tanaka, T Kumai, S F Sakata, N Tamaki, Ogura K, Nishiyama T, Watabe T, Kobayashi S. Dihydropyrimidine dehydrogenase activity and fluorouracil pharmacokinetics with liver damage induced by bile duct ligation in rats. Drug Metab Dispos. 1999;27:651-654.

8. Ray S, Roy K, Sengupta C. In vitro evaluation of protective effects of ascorbic acid and water extract of Spirulina plantesis (blue green algae) on 5-fluorouracil-induced lipid peroxidation. Acta Pol Pharm. 2007;64:335-344.

9. Oettle H, Pelzer U, Hochmuth K, Diebold T, Langrehr J, Schmidt CA, Arning M, Vogl TJ, Neuhaus P, Huhn D, Riess H. Phase I trial of gemcitabine (Gemzar), $24 \mathrm{~h}$ infusion 5-fluorouracil and folinic acid in patients with inoperable pancreatic cancer. Anticancer Drugs. 1999;10:699-704.

10. Li XP, Wen F, Yang W, Deng YB, Li M, Zhang PF, Tang RL, Li Q, Wei YQ. The role of tiopronin for the prevention of chemotherapy-related liver toxicity in advanced colorectal cancer patients treated with mFOLFOX7: a prospective analysis. Tumori. 2014;100:446-451.

11. Khan R, Khan AQ, Qamar W, Lateef A, Tahir M, Rehman MU, Ali F, Sultana $\mathrm{S}$. Chrysin protects against cisplatin-induced colon toxicity via amelioration of oxidative stress and apoptosis: probable role of p38 MAPK and p53. Toxicol Appl Pharmacol. 2012a;258:315-329.

12. Khan R, Khan AQ, Qamar W, Lateef A, Tahir M, Rehman MU, Ali F, Sultana S. Chrysin abrogates cisplatin induced oxidative stress, p53 expression, goblet cell disintegration andapoptotic responses in the jejunum of Wistar rats. Br J Nutr. 2012b;108:1574-1585.

13. Fraga GC. Plant phenolics and human health: Biochemistry, nutrition and pharmacology; John Whiley \& Sons: New Jersey: 2010.
14. Boudet A. Evolution and current status of research in phenolic compounds. Phytochem. 2007;68:2722-2735.

15. Lule SU, Xia W. Food phenolics pros and cons: A review. Food Rev Int. 2005;21:367-388

16. Kleinsorge $H$, Pohl W. [Gentisic acid in therapy of rheumatic polyarthritis]. Med Klin. 1953;48:1038-1040.

17. Clarke NE, Mosher RE, Clarke CN. Phenolic compounds in the treatment of rheumatic fever: A study of gentisic acid derivatives. Circulation. 1953;7:247-257.

18. Sharma S, Khan N, Sultana S. Modulatory effect of gentisic acid on the augmentation of biochemical events of tumor promotion stage by benzoyl peroxide and ultraviolet radiation in Swiss albino mice. Toxicol Lett. 2004;153:293-302.

19. Sharma S, Khan N, Sultana S. Study on prevention of two-stage skin carcinogenesis by Hibiscus rosa Sinensis extract and the role of its chemical constituent, gentisic acid, in the inhibition of tumour promotion response and oxidative stress in mice. Eur J Cancer Prev. 2004;13:53-63.

20. Ashidate K, Kawamura M, Mimura D, Tohda H, Miyazaki S, Teramoto T, Yamamoto Y, Hirata Y. Gentisic acid, an aspirin metabolite, inhibits oxidation of low-density lipoprotein and the formation of cholesterol ester hydroperoxides in human plasma. Eur J Pharmacol. 2005;513:173179.

21. Exner M, Hermann M, Hofbauer R, Kapiotis S, Speiser W, Heldd I, Seelose C, Gmeiner BMK. The salicylate metabolite gentisic acid, but not the parent drug, inhibits glucose autoxidation-mediated atherogenic modification of low density lipoprotein. FEBS Lett. 2000;470:47-50.

22. Hermann M, Kapiotis S, Hofbauer R, Seelos C, Held I, Gmeiner B. Salicylate promotes myeloperoxidase-initiated LDL oxidation: antagonization by its metabolite gentisic acid. Free Radic Biol Med. 1999;26:1253-1260.

23. Joshi R, Gangabhagirathi R, Venu S, Adhikari S, Mukherjee T. Antioxidant activity and free radical scavenging reactions of gentisic acid: in-vitro and pulse radiolysis studies. Free Radic Res. 2012;46:11-20.

24. Mink S, Roy Chowdhury SK, Gotes J, Cheng ZQ, Kasian K, Fernyhough P. Gentisic acid sodium salt, a phenolic compound, is superior to norepinephrine in reversing cardiovascular collapse, hepatic mitochondrial dysfunction and lactic acidemia in Pseudomonas aeruginosa septic shock in dogs. Intensive Care Med Exp. 2016;4:24.

25. Liu Z, Ciocea A, Devireddy L. Endogenous siderophore 2,5-dihydroxybenzoic acid deficiency promotes anemia and splenic iron overload in mice. Mol Cell Biol. 2014a;34:2533-2546.

26. Fernández IS, Cuevas P, Angulo J, López-Navajas P, Canales-Mayordomo A, González-Corrochano R, Lozano RM, Valverde S, Jiménez-Barbero J, Romero A, Giménez-Gallego G. Gentisic acid, a compound associated with plant defense and a metabolite of aspirin, heads a new class of in vivo fibroblast growth factor inhibitors. J Biol Chem. 2010;285:1171411729.

27. Altinoz MA, Elmaci I, Ozpinar A. Gentisic acid, a quinonoid aspirin metabolite in cancer prevention and treatment. new horizons in management of brain tumors and systemic cancers. J Cancer Res Oncobiol. 2018;1:109.

28. Nafees S, Ahmad ST, Arjumand W, Rashid S, Ali N, Sultana S. Modulatory effects of gentisic acid against genotoxicity and hepatotoxicity induced by cyclophosphamide in Swiss albino mice. J Pharm Pharmacol. 2012;64:259-267.

29. Nora EMA. Protective effect of captopril against 5- fluorouracil-induced hepato and nephrotoxicity in male albino rats. J Am Sci. 2012;8:680-685. 
30. Luna L. Manual of histological staining methods of the armed forces institute of pathology. New York, USA: McGraw-Hill Publications; 1960.

31. Perry MC. Chemotherapeutic agents and hepatotoxicity. Semin Oncol. 1992;19:551-565.

32. Molander DW, Wroblewsk F, La Due JS. Transaminase compared with cholinesterase and alkaline phosphatase an index of hepatocellular integrity. Clin Res Proc. 1955;3:20-24.

33. Ziemmerman HJ, Seef LB. Enzymes in hepatic disease. In: Goodley EL, ed. Diagnostic enzymology. Philadelphia: Lea and Febiger; 1970:1-38.

34. Tiribelli C, Ostrow JD. The molecular basis of bilirubin encephalopathy and toxicity: report of an EASL Single Topic Conference. J Hepatol. 2005;43:156-166.
35. Yanpallewara SU, Sunita R, Mohan K, Acharyaa SB. Evaluation of antioxidant and neuroprotective effect of Ocimum sanctum on transient cerebral ischemia and long-term cerebral hypoperfusion. Pharmacol Biochem Behav. 2004;79:155-164.

36. Gelen V, Şengül E, Yıldırım S, Atila G. The protective effects of naringin against 5-fluorouracil-induced hepatotoxicity and nephrotoxicity in rats. Iran J Basic Med Sci. 2018;21:404-410.

37. EL Hak HNG, Saad Moawad TI, Abdel-Aty Hafez G. Histological study of the effect of chemotherapy with 5-fluorouracil on normal liver and kidney of mice. Int J Novel Res Life Sci. 2015;2:8-13. 